\title{
NEO-MARXISME IN DIE KERKLIKE LEWE
}

DIT is makliker om oor die teologiese en filosofiese aspekte van die neo-marxisme te spreek as om iets oor die openbaring en toepassing daarvan in die kerklike lewe te sê. Ek beweer dit sonder refleksie op die hoofbestuur wat my hierdie taak opgedra het of op prof. Floor wat hom op uitnemende wyse van sy deel van die taak gekwyt het, al is dit die maklikste deel. Maar ek beweer dit omdat ek al lesende en studerende oor die saak gestuit het teen die verskynsel dat die dinge op die teologiese én kerklike terrein só vervleg is, dat die neo-marxistiese invloed dikwels moeilik uitkenbaar is. Tussen die pole en polariserende regs en links is daar 'n grys veld van vaaghede waarvan mens - dikwels na gelang van jou teologiese instelling en smaak - kán dink dat dit 'n marxistiese inslag het, maar nie noodwendig hoef te hê nie, terwyl ander sake wat beslis marxisties is, die aandag kan ontglip.

Dit is dikwels maar al te waar dat hoe regser mens teologies en kerklik georiënteer is, hoe minder humaan en bewoë mens is oor wêreldnood op politieke en sosiale gebied en hoe gouer iemand geneë sou wees om iets as kommunisties te bestempel. Daarenteë, hoe linkser iemand teologies en kerklik staan en hoe meer politiek en sosiaal hy bewoë is, hoe makliker hy kerklike sake as konserwatief en van die „establishment" bestempel en hoe minder aandag hy gee aan die verlossing en regverdiging van die sondaar. Globaal gesien val die uiters regse saam met die meer geestelike siening, die vertikale, terwyl die uiters linkse die meer materiële is, die horisontale. Ons kan ook groeper met die ooraksent op die leer teenoor die lewe, die tug, teenoor dialoog, die individuele en persoonlike teenoor die gemeenskaplike, sosiale, politieke en humane.

Hierdie teenoorstelling en onderskeiding gaan nie altyd en nie in geheel op nie, daar is nuanses en aspekte van klemverskuiwing waarop ek nie ingaan nie. Maar waarop dit wesenlik aankom is steeds m.i. drie deurslaggewende sake, nl. wie en wat is Christus? Wat is die verhouding tussen kerk en wêreld? Wat is die koninkryk van God? Die siening van die teologie en die kerklike vergaderings veral op hierdie drie sake bepaal die kerklike lewe en met name veral die prediking. Dit is ook ons iuiste begrip van hierdie drie of van die eerste en die laaste omdat die tweede tussen-in lê, na weerskante bepaal en bepalend, wat ons oë oopmaak vir die neo-marxisme in die kerklike lewe. Prof. Floor het reeds hierop gewys in sy rede. 'n Enkele verwysing daarby na 'n werk van die vroeë dertiger jare, kan nog meer verhelderend werk: dr. Van den Bergh van Eysinga wy in sy „Revolutionnair Cultuur" ook 'n hoofstuk aan Revolutionnaire Theologie. Daarin maak hy die Christologie tot 'n sosialistiese leer van die Christus in ons, die koning van die verdrukte kreature, die groot liefde. Die Christus vereenselwig hy met die kommunisme; Hy word verag, bespot, gedood, gekruisig - maar hy staan op uit die dode, die idee sal oorwin en woon in die nuwe mense. Die vernuwing het kosmiese betekenis en bring die aarde verlossing 
in 'n nuwe ryk van vrede, die sosialistiese heilstaat vol geregtigheid, sonder onderdrukking en armoede en eensydige rykdom. Dit is ' $n$ ideaalstaat van ontwapening. Die marxistiese heilstaat word vereenselwig met die koninkryk van God.

Sulke growwe en moontlik ander meer verfynde vermenging van die marxistiese ideologie en die Evangelie van Christus lê voor die hand. Die kerk, die gelowiges kry in die wêreld te doen met die groot politieke, sosiale en ekonomiese vraagstukke van die wêreld. Dr. C. A. van Peursen skrywe oor die vraagstukke 'n boek ,Strategie van de Cultuur" met subtitel „Een beeld van de verandering in de hedendaagse denk- en leefwereld"; 'n kultuurpatroon het verbygegaan waarna ons nie moet terugverlang nie. Ook dr. $H$. R. Rookmaker het hieroor gedagtes in sy „Modern Art and the Death of a Culture". In die laaste hoofstuk "Christian in a changing World" skryf hy: „... it is hard to se a great culture breaking down around us, even though... it is not really based on Christian principles, but on those of the Enlightenment. But for that very reason, these are exciting times. God has called us to bear witness to Him at a critical point of history" (aangehaal deur B. Rietveld, Wat is er aan de hand met de Geref. Kerken in Nederland, bl. 13).

By die verandering is daar verlange na 'n magtige deurbraak van die koninkryk van God desnoods langs revolusionêre weg; die verlange laat die kerk dialoog voer met die kommunisme. Die wêreld is in angs vanweë die moontlikheid van selfuitwissing; bewapening, oorlog en vrede word dié vraagstukke. Statistiese en volkekundiges wys op die bevolkingsontploffing wat ondergang beteken; die Club van Rome berig dat daar reeds te min voedsel vir die mens is; in die ekonomie is dit inflasie en lone en rykdom-armoede en ontwikkelingshulp en -lande wat aandag vra. In die gemeenskapslewe word aborsie, die pil, homofilie, euthenasie swaar geaksentueer. Deurgetrek op volkerelewe is dit rasseverhoudings, dekolonisasie, skuldgevoel oor koloniale verlede en misdrywe soos slawehandel, vryheidsbewegings en terroriste. 'n Nuwe maatskappy moet gevorm word.

Lidmate het elke dag in meerdere of mindere mate te doen met al die vrae. Moderne kommunikasiemiddels hou dit meedoënloos onder sy aandag. Meer en meer gebeur dit dat daar geen dag verbygaan nie of die pers en radio en TV vra die predikant om sy mening of "die kerk se mening" oor die sake. In die kerke loop die reaksie op die wêreldgebeure uiteen: daar is diegene wat die kerk by alles betrokke wil sien as daadwerklike deelnemer tot die verwesenliking van die ryk van vrede en rus, die koninkryk hier en nou. Ander lê nadruk op die enkele gelowige en wat in sy hart gebeur. Die aksie van kerke, ekumeniese bewegings en individuele lidmate is toegespits op verwerkliking van die sigbare ryk. Maar hiermee is ook die wêreld besig. Besonderlik het die neomarxisme met hierdie vrae te doen en bied hy sy oplossing aan van verandering, afbraak van strukture, rewolusie en die verkryging van die heilstaat. Teologie en kerk ontmoet hier die marxistiese 
idees en aksie asof daar 'n gemeenskaplike doel is, nl. die heilstaat of die koninkryk van God.

Ooreenkomstig die idees van Tillich oor 'n ongenormeerde gesprek om tot die waarheid te kom - dit het mede gelei tot die sg. "teologie van die dialoog" - het teoloë in gesprek getree met die kommuniste. Die dialoog sal immers lei tot die oplossing van die vraagstukke en/of die bereiking van die ryk hier en nou. Soos paddastoele het in die Westerse lande, ook S.A. deur kerklike bemoeienis gesprekskringe, gemeenskappe, -byeenkomste en dies meer opgespring. As die dialoog ongenormeer is en bedoel om tot die waarheid te kom, kán daar immers, sonder die hinderlike en altyd bindende van Woord en belydenis gepraat word met enige-iemand. „Een jonge generatie kijkt naar marxisten. Er moet een nieuwe maatschappij gevormd worden. De tijd voor individuele vrijheid schijnt voorbij. Is er verwantschap tussen hen, die van Christus geleerd hebben zorg te dragen voor de naaste en anderen, die toch hetzelfde voorstaan? Maar waar komt stalinisme vandaan? Is er een sosialisme met menselijk gelaat, waarin christenen zouden kunnen delen? En verder gaat de dialoog" (Rietveld, a.w., bl. 15). As dit alles so is moet dit ons nie verbaas nie as oortuigde kommuniste ook ingeskrewe teologiese studente kan wees nie, soos in Kampen.

Maar die kerkwerk is nie net dialoog nie. Op die woord moet die daad volg, kerklike aktivisme, die dade-christendom. Die kerk moet aandeel hê in die aktiewe verkryging van die nuwe maatskappy en die heilstaat. Deur sy mondiale betrokkenheid moet die kerk ook politieke en sosiale aksiegroep wees, dit by uitstek wees; hy moet sy presensie in die wêreld aksentueer, sy maatskaplike betrokkenheid laat geld.

Die aktivisme beteken vir die kerk enorme vergroting van sy verantwoordelikheid van sy werk wat nie meer inpas in die tradisionele vorme van kerkwees en kerkwerk nie. Daarom moet die vorme of strukture verander word, desnoods langs revolusionêre weg sodat opening en ruimte gemaak word vir die aksie. Die aksie van die kerk loop parallel met die aksie van die marxiste; die een neem die ander oor - tree in die huwelik volgens prof. Floor - en baar kinders van storm. Vandaar die opmerklike verklaring van een van die opstellers van die berugte Rapport PCR wat voor die Sinode GKN gedien het: by alles wat ons gepraat het oor die rasseproblematiek moet ons nou uiteindelik ook doen, nl. geld gee vir die PCR, d.w.s. vryheids- of terroristebewegings.

Die stormkinders trek die kerk deur sy vaderskap diep in die politieke en maatskaplike vraagstukke in en dwing hom tot aksie. Hoe meer die aksies interdenominasioneel, internasionaal, supranasionaal, ekumenies en mondiaal kan plaasvind, hoe beter. En dan word dit aksies soos die PCR, wêrelddiakonaat, ontwikkelingshulp, deel hê aan optogte en demonstrasies en dies meer. Maar die stormkinders dring steeds meer aan op „geen woorde nie, dog dade" en sing so saam in die koor van die goddelose marxisme (drs. H. de Jong, Wat vindt $u$ van het getuigenis, bl. 48). Dit moet hom ook openbaar in sending en evangelisasie wat omvattende aktiwiteite 
moet wees, nl. die mediese wetenskap, tegniese hulp, sielkundige hulp en behuisingshulp moet daarin aksente ontvang, daarvoor moet geld gegee word. In die hele grote aktivisme van die kerk is die enkele gelowige nie meer so belangrik nie, nie die bekeerde en dankbare hart van 'n geredde sondaar nie, maar die geöliede organisasie van die gemeenskap; só kan die kerk 'n duidelik omskrewe en kreatiewe bydrae lewer tot versterking van die vrede in samewerking met ander maatskaplike kragte wat tot die vrede wil kom deur revolusie en bevryding (Kirchhof in Karl Marx en Lenin als kerkvaders, A. J. Visser, bl. 53). Ook so kan die gesamentlike verantwoordelikheid van Christene en marxiste 'n hoër kwaliteit van samewerking vir vrede en die versterking van die sosialistiese staat te weeg bring (a.w., bl. 53).

Die beklemtoning van die daad bo die woord deur die neomarxisme beteken nie dat rofweg skeiding gemaak word tussen Woordverkondiging en diakonia van die kerk nie. Daarvoor is die Skrifgetuienis te sterk. Dit beteken tewens ook dat die daad van die kerk gedra moet word deur die teologie, vandaar die ouere en meer bekende teologie van die rewolusie en die nuwere teologie van die dialoog, van die bevryding, van die ateísme (vgl. A. J. Visser, a.w., bl. 41) en, mag die Here ons behoed, 'n eindelose galery van teologieë wat met Gods-kennis niks meer uit te staan het nie.

Oor die verskillende „teologieë" is reeds gespreek. Ons moet egter daarop let dat die teologieë deurwerk in die kerklike aktiwiteit. Omdat ons in 'n rewolusionêre tyd lewe (A. J. Visser, bl. 43) is die kerk, ook in sy prediking, steeds meer besig met die kategorieë ,geskiedenis en toekoms”; maar die Marxisme stel hierdie begrippe van begin af aan sentraal. Daarom kan die teologie van die dialoog van toepassing gemaak word en die teologie van die rewolusie en die bevryding kan gepredik word.

Dit word dan kritiese teologie en kritiese prediking wat alles inmekaar skuiwe - subjek, objek, geloof en geskiedenis, kerk en wêreld, hede en toekoms, kreatiwiteit en wetmatigheid. Die totale rewolusie het die prioriteit. En as die mensdom eers goed en wel bevry is sal blyk dat ook die kerk en die prediking sy rol uitgespeel het want daar sal 'n utopia wees!

In die politiek-betrokke marxistiese teologie is Jesus Christus niks anders nie as die prototipe van die rebel, die rewolusieleier in 'n messiaanse rewolusie op weg na die ryk van menslikheid en geregtigheid. Jesus hang aan die kruis van ons verskriklike werklikheid. Die kerk se taak is om Hom tot opstanding te bring deur die prediking en die diakonia. (Op meerdere kansels is die geloofsbelydenis van Dorothee Sölle waarin hierdie siening op Christus verwoord is, voorgelees, vgl. Getuigenis, bl. 56.)

Die prediking is daarop gerig om ons Jesus as die bevryder uit sosiale en politieke nood voor te hou. Die kerk moet hom derhalwe vereenselwig met bepaalde politieke en maatskaplike stellings wat van die kansel kom. En wanneer 'n geregtigheid voorgehou word wat volkome gesekulariseer is, losgemaak uit Bybelse verbande en ook van die barmhartigheid wat Jesus leer, kan mens 
die neo-marxis uitken. Met die sonde en die redding uit die sonde en sy verskriklike gevolge het dié geregtigheid nie te make nie, wel met politieke en sosiale sake waarvoor die Here Jesus gekom het. Die sentrale van die wet van God, nl. liefde tot God en die naaste, kom daarin nie voor nie. Die verbinding geregtigheid liefde is sosiale geregtigheid en mede-menslikheid. Ene dr. Ter Schegget, filosoof en dosent in die filosofie in Driebergen, Nederland, verklaar in hierdie verband dat hy Marx leer ken het in die lig van Jesus van Nasaret. ,Jezus heeft ons op een totaal andere manier God leren zien. De God van Jezus is de God van de Exodus als het ware een anti-god. Hij bevrijdde zijn volk niet alleen uit de sosiale, maar ook uit de godsdienstige slavernij van de farao... De God van Jezus is dan ook de God van de maatschappelijke en religieuse ontrechten, zoals iedere slavernij in wezen zowel sociaal als religieus is. Het gaat Hem om de anderen die niet meetellen. Daarom verkeert Jezus gedurig onder de anderen in zijn maatschappij, te weten de armen, tollenaars, hoeren ens...." Die „ontrechten" is altyd die wat deel uitmaak van die produksiemiddele, huurslawe wat deur hul dienste van hulself vervreem word. Die kerk en die prediking van die na-Constantynse tydperk het die subversiewe, revolusionêre evangelie wat bevry en wat Jesus gebring het, vervals. Hierdie valse kerk gaan as instituut onder en sy anti-bevrydende prediking is inderdaad niks anders nie as opium van die volk (vgl. Opbouw, 12-12-75, bl. 376).

Ek wil hierdie gedeelte wat moeilik is en waarin ek taamlik heen en weer gepraat het om deur ,tyd opmaak" $u$ te beïndruk, afsluit met verwysing na 3 preke, een gelewer in ' $n$ Gereformeerde Kerk in Nederland, een deur 'n predikant van die GKN gelewer in Pretoria en een van 'n predikant van 'n Afrikaanse kerk. Die teks vir die eerste het my ontgaan; dit was 'n tirade teen die verderflike rassebeleid in Suid-Afrika en 'n oproep om geld te gee vir die PCR-fonds ter ondersteuning van vryheidsbewegings afgesien daarvan of dit Christene is al dan nie - die doel van geregtigheid, d.w.s. dat die ,under-dog", „top-dog" sou word in die bevrydingsliefde van Christus, gee die deurslag.

Die tweede het gehandel oor die opwekking van die seun van die weduwee van Naîn: Christus het die vrou bevry van die sosiale nood waarin sy verkeer het, nl. dat haar man haar ontval het, die seun - enigste sorg - ook dood is en onversorgdheid haar in die oë gestaar het; Jesus het gekom om die sosiale nood van die mense weg te neem, om die gemeenskap te bevry van sosiale onversorgdheid en ons die weg gewys van sosiale versorging; hierby is te pas gebring, die ongeregtigheid wat in die wêreld heers vanweë die ryk-arm teëstelling en in S.A. vanweë die loongaping tussen wit en swart.

Die derde het dit oor die gelykenis van die barmhartige Samaritaan gehad: naaste beteken medemens; waarop Jesus wys in die gelykenis is die eis van medemenslikheid; dit is die sleutel waarmee die goeie verhoudinge tussen rasse oopgesluit word; die swartes lê langs die pad, beroof, aangerand, verneder, uitgebuit 
en dies meer; die Engelse en Afrikaners loop verby; wie sal in ons samelewing die barmhartige wees, die medemenslike groep? Maar genoeg van hierdie dinge waarvan u meer weet as ek. Laat ons na 'n antwoord van die kerk soek op die gevaar van die neo-marxisme in die kerklike lewe. Die antwoord sal hom uit die aard van die saak toespits op twee sake, t.w. kerk en wêreld en die koninkryk van God. Ons is nie die eerste wat tot so 'n antwoord geroep word nie. Veeleer staan ons om allerlei redes taamlik agter in die ry. Daarom laat ek eers drie geskrifte aan die woord waarna ons met vrug kan luister. Dit is die "Getuigenis" van 'n aantal teoloë van die Nederlandse Hervormde Kerk, 1972, die "Geloofsgetuigenis" van die Generale Synode van Haarlem van De Gereformeerde Kerken in Nederland 1974 en die Rapport oor Menslike verhoudings van die Algemene Sinode van die NGK van S.A.

\section{Die getuigenis}

„Het is overduidelijk dat de huidige kerkelijke crisis een geloofscrisis is en ... dat de veranderingen in theologie en prediking een volledige breuk met het verleden der kerk gaan betekenen... Men acht religie en geloofsworsteling een overwonnen zaak, bekommernis om het persoonlijk heil een vorm van zelfzucht. ... Hij (God) wordt getrokken binnen de grenzen van ons bestaan omdat wij boven en buiten onze horizon geen werkelijkheid meer willen erkennen. Dat is de diepste reden dat in deze tijd het Evangelie geabsorbeerd wordt door de geschiedenis en dat de historie schijnt te zullen uitmonden in het koninkrijk Gods. De mens... kan de Bijbel niet anders meer verstaan dan binnenwerelds. Het Evangelie wordt zo tot een verwereldlijkte (geseculariseerde) Messianisme ... De Christologie wordt tot een Jesulogie waarin Christus wordt getekend als de aardse ,Jezus-Messias' en ,de Man van Nazaret', die alle trekken draagt van de revolutionaire afgoden van deze tijd. Het Rijk Gods wordt een afspiegeling van radicale, revolutionaire, politieke wensdromen. De beoogde vrijheid, die in wezen de mens onderwerpt aan en slaaf maakt van de wetten van zijn eigen bestaansituatie, is een geheel andere dan de vrijheid van de heerlijkheid van de kinderen Gods (Rom. $8: 21$ ). ... Ons Getuigenis richt zich met name tegen de hoogmoedige en onverdraagzame mentaliteit, die het Evangelie verbastert tot puur aards messianisme. Tegen een onschriftuurlijke werkheiligheid, die het Christelijke geloof vereenzelvigt met een bepaalde maatschappelijke en politieke betrokkenheid. Tegen een moderne syncretisme, waarbij de belofte van het Koninkri.k Gods vermengd wordt met ideëen, die hun oorsprong niet vinden in de Bijbel, maar in humanistische en ateistische ideologieën. Tegen een verpolitisering en vermaatschappelijking van het heil in de zin van een opstand tegen de gevestigde orde (het zogenaamde ,establishment") en een omverwerping van de huidige maatschappelijke, politieke orde en structuren.

De Bijbel spreekt totaal anders over de mens en zijn verlossing. Daar wordt de mens allereerst als verantwoordelijke enkeling voor God en de medemens gesteld. Vandaar dat het Koninkrijk Gods 
niet in de eerste plaats is een verandering van politieke orde en maatschappelijke structuren, maar een verandering in de verhouding tot God en medemens. Wél klinkt in de Bijbel het protest tegen duidelijk aanwijsbaar onrecht in de samenleving, maar steeds in verband met de innerlijke verhouding tot God en de medemens in geloof en bekering (Amos 8 en 4).... Hoewel de gelovige oog heeft voor zijn verantwoordelijkheid ten aanzien van wereldse taken en opdrachten, leeft hij zo sterk bij het besef van de voorlopigheid van deze wereld en dit leven, dat hij een innerlijke reserve koestert tegenover elke politieke en sosiale druk om het heil in het „hier en nu" te leggen.

1. De liefde tot God en de liefde tot de naaste vallen niet samen, zodat men het Evangelie niet in medemenselijkheid mag laten opgaan: Daarom protesteren wij tegen de aan minachting grenzende wijze, waarop - over de liturgiese dienst van de gemeente en de vroomheid van de gelovige gesproken wordt. ... Wanneer het persoonlijk geloofsleven en de samenkomst van de gemeente... vanuit een overdreven activisme en eenzijdig daad-christendom als overbodige religiositeit worden afgedaan, dan treft men het geloofsleven van de gemeente in het hart.

2. De rechtvaardiging van de goddeloze (Rom. 4 en 5 ) gaat aan de heiliging en de goede werken vooraf; ... de vergeving der zonden kan en mag niet door maatschappelijke en politieke geëngageerdheid worden verslonden. ...geloof leeft van onverdiende genade van God en niet van menselijke prestasies... Evenzeer bestrijden wij een christelijke praktijk, die louter en alleen de daad en de medemenselijkheid op het oog heeft en van onverdiende genade niet meer wil weten". Wie erns maak met dic heiliging en dankbaarheidslewe, en dus ók met politieke en maatskaplike betrokkenheid, sal altyd weer terug val op die regverdiging, die vergewing van die zonde.

3. Ons verset ons teen die verpolitisering van die leerstuk van die versoening waardeur dit in die versoening slegs sou gaan om die verhouding van mens tot mens, van volk tot volk. Niemand het die reg om die versoening wat deur God se genade in Christus bewerk is, in menslik-, eties-, politieke en sosiale handelinge te laat opgaan nie.

4. Die vleeswording, kruis en opstanding van Jesus bly die onwrikbare, objektiewe fondament van die Christelike geloof. „Wij verzetten ons tegen een theologie en prediking, die... de méns Jezus van Nazaret aan het kruis ziet hangen als simbool van alle menselijke leed en onrecht in deze wereld...

5. Wij keren ons tegen zulk een leer en prediking... dat wij... door onze politieke en maatschappelijke geëngageerdheid, Christus tot opstanding zou moeten brengen...

6. Die heil kom van God as 'n wonder van sy genade en word deur Hom en nie deur die menslike historie gerealiseer nie. „Wij verwerpen een theologie en prediking, die God afhankelijk maken van de historische ontwikkelingen. ... Het heil van God komt niet tot ons door de evoluties en de revoluties van de geschiedenis... 
Om deze redenen verwerpen en bestrijden wij de ideologisering van het christelijk geloof, die dit geloof laat samenvallen met een ideologie der revolutie.

7. Wij verzetten ons tegen een moderne zondeleer, die de zonde allereerst zoekt in de politieke en maatschappelijke structuren. ... de prediking van de kerk (zal) de mensen moeten oproepen tot persoonlijk geloof en bekering. Maatschappelijke en politieke problemen kunnen alleen... worden opgelost, als de mens persoonlijk door Christus gegrepen, vernieuwd en veranderd is".

Tot sover die „Getuigenis” van die Hervormde teoloë.

\section{"Geloof sgetuigenis"}

Die opdrag was om 'n eenparige geloofsgetuienis op te stel wat as basis kon dien ,voor een nieuw belijden in gemeenschap des geloofs met het belijden der vaderen". Dit moet aan die sentrale inhoud van God se Woord beantwoord en op verskillende eietydse vrae ingaan. Die getuienis moet nie leeg staan t.o.v. die vrae nie maar sy indringende krag bewys waar die vrae hulle vermenigvuldig. Niks is gevaarliker nie as dat die kerk sou meen om alle vrae in 'n eie kompetensie op te los nie. Aan die ander kant moet die kerk die vraagstukke nie vrees nie, hy moet probeer om die weg te wys.

1. Oor „Het Rijk van Christus” lui die Geloofsgetuigenis: „Wij geloven dat het Rijk van Christus in de wereld is ingegaan als een verlossende, geestelijke heerschappij om de strijd aan te binden tegen de machten van duisternis, zonde en dood, die het leven van de mensen knechten. Christus oefent deze heerschappij uit door zijn Woord en door de Heilige Geest als de bediening der verzoening ( 2 Kor. $5: 18,19)$ en wij geloven dat God allen, die daaraan gehoor geven, verlost uit de macht van de duisternis en overbrengt in het koninkrijk van de zoon van zi n liefde. Deze heerschappij... wordt ons gepredikt als de triomferende ontwapening van alle overheden en machten (Kol. $2: 15$ ). ... deze heerschappij van Christus (beperkt) zich niet tot een bepaald levensverband, ook niet tot dat van de kerk, maar openbaart zich, waar zij ontvangen wordt, als een bevrijdende en vernieuwende macht in heel het leven der mensen. Zij sticht vrede en gerechtigheid, zij bindt de strijd aan tegen onrecht en onderdrukking... En hoewel er vele krachten in de wereld zijn, die het leven willen bevrijden van ellende en onrecht... zo is nochtans de heerschappij van Christus daarin te onderscheiden en te kennen, dat zij ons de verlossing van het leven niet eerst zoeken in de eigen macht of wil... maar in de kracht van zijn bloed en van zijn geest en in de terugkeer van de mens tot God.

2. God het sy gemeente uit die wêreld geroep, so lui dit, en so onderskeid gemaak tussen kerk en wêreld. „Wij verstaan onder de wereld het van de ware God en zijn dienst vervreemde leven". Die kerk se afsondering is nie wesensmatig nie, maar wel sy bestaan in die toewyding van die lewe aan God, die verstaan en betrag van sy wil in die stryd teen die sonde en die gevolglike nie-gelykvormig wees aan die wêreld nie. Die kerk moet hom gelykelik laat 
bepaal deur God se liefde tot die wêreld en God se afkeer van die sonde. „Daarom mag de kerk zich niet uit de wereld terugtrekken, als was deze door God prijsgegeven aan de machten van zonde en verderf; maar zij is geroepen om in navolging van haar Heer, het Evangelie te verkondigen, en zich met hulp en liefde te wenden tot hetgeen verloren is, tot de armen en verdrukten; ook de strijd aan te binden voor de vrede onder de volkeren en voor het scheppen en instandhouden van zulke ordeningen, die vrijheid en rechtvaardigheid voor alle mensen bevorderen..."

In die Bezinning op die Geloofsgetuigenis word dit breër uitgewerk: al gaan die enkeling in sy nood en skuld nimmer skuil agter die wye wêreld nie, betuig die Evangelie tog dat God die wêreld liefgehad het (Joh. $3: 16$ ). En met 'n beroep op die barmhartigheid van God (Rom. $12: 1$ ) word ons opgeroep tot 'n lewe van vernuwing in hierdie wêreld, en om te luister na die nuwe gebod van die vryheid waarmee Christus ons vrymaak, tot liefde vir ons vyande. Die liefde wat in en deur die kerk gepredik word maak die kerk tot 'n lig van die wêreld (Matt. 5 : 13 v.).

Vanuit die evangelie ontstaan daar 'n diepgaande belangstelling vir die aardse lewe van die mense. „Wie de intense aandacht voor het leven en de gemeenschap der mensen in deze wereld in al hun nood en kwetsbaarheid al te spoedig zou willen interpreteren als secularisatie en als verschuiving van de aandacht ván de dienst van God náár die der mensen, miskent de diepte van de navolging van Christus (Ef. $5: 1$ ) ... Deze toesluiting miskent de Goddeli.ke aandacht, de aandacht van Jezus voor mensen in nood, in armoede en verdrukking, in ziekte en doodsgevaar, mensen in de verlorenheid van hun bestaan.

Van hieruit word van de gemeente niet een beperkte aandacht voor die nood gevraagd maar de totale aandacht vanwege de Goddelijke bemoeienis en aandacht. ... De wereldgelijkvormigheid ligt niet en kan niet liggen in de intensiteit van de aandacht voor dingen en mensen in deze wereld, maar alleen in de waan van de mens, die in een hoogmoedig zelfbesef meent de wereld met de diepten van zijn binnenste... te dienen en verrijken". Op grond van God se aandag ,is de interesse der gemeente onbegrensd, juist haar interesse voor vrede en gerechtigheid, voor de volkeren, - alle volkeren - en voor zulk een leven in verhoudingen waarin vrijheid en rechtvaardigheid voor alle mensen worden bevorderd".

Vir hierdie aandag moet die kerk op sy hoede wees teen vervreemding van die Woord en van God se goedertierenheid (Titus $3: 4)$. Dit sou lei tot die poging om die wêreld te red deur puur menslike barmhartigheid. Dit is heilsaam en noodsaaklik om gewaarsku te wees vir wat by mense moontlik is (vgl. Dawid wat nie in die hand van mense wil val nie, Jona wat nie sorge vir Ninevé het nie). „Het herinnert ons aan een wereld vol discriminatie (niet alleen der rassen), aan een wereld zonder gehoor voor het Goddelijk welbehagen in mensen... Gewaarschuwd wordt tegen alle gevaren van het menselijk ",bewuste" en in het besef dat ons christelijk leven nog menigmaal bedreigd en geschokt wordt, zal 
de kerk in haar verwachting mogen en moeten uitzien naar Gods voleinding van het Messiaanse rijk. Ze zal weten dat Zijn heil niet opgaat in onze daden..."

\section{Die rapport van die NGKSA}

Die rapport stel die volgende oor die kwessies kerk en wêreld en koninkryk van God en ons houding jeens die vrae van die tyd: "The church calls to obedience in all spheres of life, the whole of human life in all its facets... This does not imply that the whole of humanity will respond to or be part of the Kingdom! There will always be tension in the church's involvement and in its antithesis to the world. If the church should concern itself only with the world it leads to horizontalism, if it should concern itself only with the cultivation of personal piety, it fails in its calling to challenge the entire society to be subject to the demands of God and His Word!

The fulfilment of its calling presupposes the involvement with the people... The church that pronounces itself for or against the power structures within the state repudiates its own being and ontogenous existence on the other hand: The church must fulfil its prophetic, priestly and kingly function also towards the people. ... (A community) is both the object of God's loving concern and the area where Satan manifests his power. ... The church will have to be clear and uncisive in its testimony. Thus the church is for the people and at the same time against the sins of the people, for the sake of the preservation of the people. ... In it's visible structure the church should not exist divorced from the people to whom it must preach the Word.

Neighbourly love should be the decisive norm for social justice. Although social injustice is seen as a consequence of man's sinful nature, the church can never acquiesce in this situation but must do everything in its power within it's own sphere to realise the message of the redemption of Christ and his Kingdom amidst "a crooked and perverse" generation (Phil. 2 : 15).

The church cannot stand aloof from the socio-economic problems of less developed peoples and of developing peoples... Comprehensive development programmes... are not the responsibilities... of the church. The church is specially equiped with the instruments of grace as well as the service of the diaconate (which) is all indication of the breakthrough of the Kingdom of God in this world. This position is in sharp contrast to the decision of the World Council of Churches to establish ... a section for development and with its own development fund. In this manner the function of the church is broadened to such an extent that it is moving ever further away from the cross of Christ... In the process of consistent horizontalisation, the church runs the risk of substituting the improvement of the world for the preaching of the Word of God. The coming of the Kingdom of God may not be identified with economic development. Development aid cannot be substituted for 
missionary work, preaching the gospel, regeneration or conversion. The church of a spiritual basis of a Christian philosophy of life and creation of a spiritual fasis of a Christian philosophy of life and could view... The church should welcome... orderly and sound development... by the authorities and other non-church bodies. It is the function of the church to bring to the attention... any plight, need or injustice that may occur. The church itself may never ignore the plight and needs of people, but should provide assistance through a purposeful diaconate and broadly based charitable services and should activate the congregation to undertake relief services for the benefit of their neighbours".

Tot sover hierdie drie antwoorde waarby ek my saaklik kan aansluit. 'n Eie antwoord kan dus stellinggewys en kort wees:

1. Die kerk moet hom kragtig en stewig ingrawe by die leer van die persoonlike heil wat die Reformasie weer so Skriftuurlik aan hom gegee het. Dit is die fort wat Christus en die apostels as enigste fondament het; vanuit die verskansing van die genade alleen, die geloof alleen, die Skrif alleen, Christus Jesus alleen en die eer aan God alleen, moet die stryd gevoer word. Dié weg bring ons Skriftuurlik van die gelowige op die gelowiges, die ledemaat op die liggaam, die gelowiges in die wêreld, in die koninkryk van God.

2. Die kerk moet voluit lewe uit die Koningskap van sy Hoof Jesus Christus (Ef. 1 : 22, Kol. 1) teenoor 'n ongemagtigde en wêreldse anneksasie van „Jesus van Nasaret" vir 'n versmalde en verskraalde politieke teologie. Hiervoor is noodsaaklik - ek spreek vanuit my eie kerklidmaatskap as bewoënheid:

2.1. Kennis en nogmaals kennis van die Woord van God. Veel meer wat die Bybel in ons prediking figureer; veel meer Bybelstudie is noodsaaklik in die gemeente.

2.2. Sinvol en kragtig en jeugdig besig wees met ons Reformatoriese erfenis, veral ons belydenis. Ons moet kan antwoord, ook vanuit ons belydenis en belydenisvernuwing op die vrae van ons tyd.

2.3. 'n Geinspireerde en dinamiese aanpak in opleiding, studie en publikasie van die dogmatiek.

2.4. Vanuit hierdie gedeë kennis en deurgronding van die kommunisme, neo-marxisme, sionisme om ook 'n oop oog te kry vir waarheid en leuen in die wêreld van ons tyd deur die kommunikasiemiddels van ons tyd terwyl ons onthou wat Paulus ons geleer het - ook en veral veel betekenis vir óns tyd oor die krag van die dwaling en die geloof in die leuen (2 Thes. 2 : 11).

3. Die kerk moet, veral in die prediking, bly uitgaan van die versoening van die mens met God deur die voldoening van Christus Jesus. Dit is die blye boodskap van die verlossing uit die sonde en die dood; so is ons geregverdig en het ons vrede by God deur onse Here Jesus Christus (Rom. 5:1). Hieruit en gegrond hierop sal die kerk die wêreld verstaan, sy eie verdrukkinge in eie leed en verdriet en ook in die smart en problematiek van die wêreld verstaan en daarin roem. Versoening tussen mense en volke en rasse is etiese konsekwensies van dié versoening, maar dit is nie die 
versoening self nie soos die neo-marxisme leer nie. Daarom moet ons ook voluit en sonder vrees wys op die sosiale, politieke en humane implikasies van die Evangelie van die versoening. In die eie kerklike lewe en in die lewe van die kerk in die wêreld, in eie land en in eie volk moet die vrug van dié versoening gedra word.

4. Daarom eweneens moet die kerk in sy getuienis op sy hoede wees vir die valse vrede, veiligheid, sosiale geregtigheid, vryheid, gelykheid ens. wat die produk is van die onbybelse versoeningsgedagtes. Hy moet oplet dat dialoog vanuit die waarheid is, genormeerd, dat die naasteliefde as Bybelse begrip nie verruil word vir medemenslikheid, die innig persoonlike wat die Bybel vereis in die tweede groot gebod nie vir 'n onpersoonlike humanistiese mensheidsliefde nie. Ook moet hy die leuen van die ,geen verskil tussen rasse of volke nie" en van die negering van natuurlike en gesonde diskriminasie onderskei van die Skrif se waarheid. Hy moet hom verset teen die ewolusionisme van die neo-marxis met sy heilstaat en sy tese-antitese-rewolusie, maar ook die biologiese ewolusionisme waarop ons TV ons so konsekwent trakteer. Die kerk moet uit hierdie dinge en uit die geskiedenis leer wat God se Woord hom leer, naamlik dat ons na die tyd van die antichris en die wederkoms van Christus toe lewe, dat die dinge gou moet gebeur (Openb. 1 en 21) en dat die tyd kort is (1 Kor. 7), en verwerp dat die geskiedenis steeds weer universele heilsgeskiedenis word deur die proses van ewolusie en rewolusie.

5. Die kerk moet die wêreld ook raaksien as Gód se wêreld. Hy moet diepgaande aandag gee aan die nood en problematiek van die wêreld en nie huiwer om die "so sê die HERE" te laat weerklink nie. Maar hy moet daarmee paar die bewoë diakonia gebore uit die verlossende woord en leer om goed te doen aan alle mense en nie alleen aan die huisgenote van die geloof nie. Hy moet hom met 'n daad rig op die wêreld wat onder die vloek lê. So moet die kerk kragtens die Woord-mag en die diakonia opdrag spreek en doen. Die kerk wat getrou is aan die Woord en erns maak met die diakonia, is uiters gevoelig vir reg en geregtigheid. Hy sal nie alleen met diepe meegevoel kennis neem van alle onreg en verdrukking in die wêreld nie (bv. Klaagl. $3: 34-36$ ) want hy is elke dag met en van alle dinge wêreldwyd geïnformeer, maar hy sal ook by die vertikale "so sê die HERE" die onmisbaar horisontale gee van wêreldwye betrokkenheid. So moet die kerk uit die afgeslotenheid en isolement uitbreek na die wêreld toe, maar hy moet nie die strukture van die sigbare instituut afbreek nie. Die verkondiging bly - dit maak die kerke vol en nie koffie of orkeste nie, want die kerk is opgekoppel aan die kragbron Jesus Christus en daarom ook aan die netwerk wat kruis en dwars deur die wêreld loop.

6. Om waaragtig weerstand te kan bied teen die verderflike en dikwels verleidelike humanisme en wat daartoe lei in die teologie en kerklike lewe in die algemeen, is dit noodsaaklik vir die GKSA om een kant te gaan en baie deeglik en ootmoedig selfondersoek te doen. Daar is baie aanduiding van verstarring en versterwing wat kragtig afgebreek moet word. Hy sal hom moet vergewis van sy 


\section{In die Skriflig}

koninkryksroeping in die wêreld en in die ekumene op veel dinamieser, lewenskragtiger en daadkragtiger wyse as nou. Hy sal dan ook raaksien waartoe die Here werklik roep in S.A. raaksien ook die seëninge wat die Here reeds daartoe gee. So sal hy die koninklike weg kan gaan agter Jesus Christus aan na die ewige glorieryk van God.

K. S. van Wyk de Vries.

(Voordrag gelewer op G.T.V.-jaarvergadering te Krugersdorp)

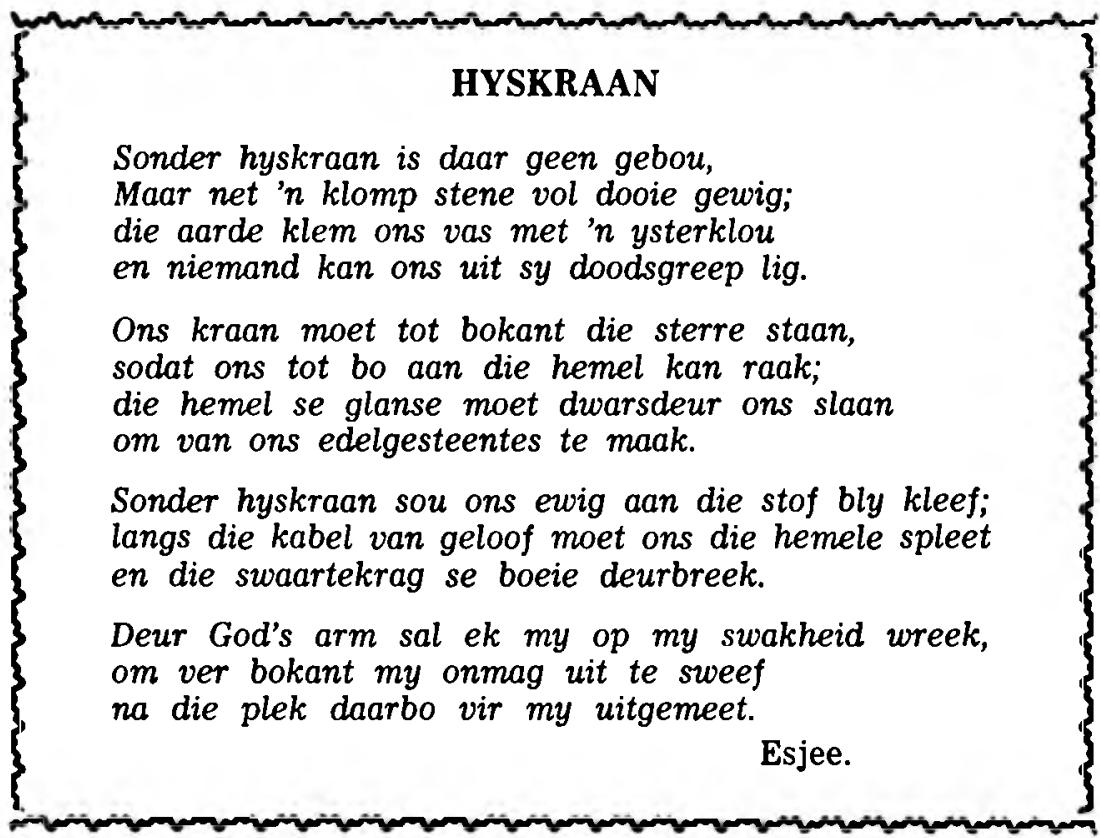

